Report Title:

\title{
Development of Novel Electrocatalysts for Proton Exchange Membrane Fuel Cells
}

Report Type: FINAL

Reporting Period Start Date: 09/01/1998 End Date: 12/31/2002

Principal Author(s): Shamsuddin Ilias

Report Issue Date: April 24, 2003 DOE Award No.: DE-FG26-98FT40146

Name and Address of Submitting Organization:

North Carolina A\&T State University

Department of Chemical Engineering

Greensboro, NC 27411

E-mail: ilias@ncat.edu

Tel: (336) 334-7564 Fax: (336) 334-7904 


\section{DISCLAIMER}

This report was prepared as an account of work sponsored by an agency of the United States Government. Neither the United States Government nor any agency thereof, nor any of their employees, makes any warranty, express or implied, or assumes any legal liability or responsibility for the accuracy, completeness, or usefulness of any information, apparatus, product, or process disclosed, or represents that its use would not infringe privately owned rights. Reference herein to any specific commercial product, process, or service by trade name, trademark, manufacturer, or otherwise does not necessarily constitute or imply its endorsement, recommendation, or favoring by the United States Government or any agency thereof. The views and opinions of authors expressed herein do not necessarily state or reflect those of the United States Government or any agency thereof. 


\begin{abstract}
Fuel cells are electrochemical devices that convert the available chemical free energy directly into electrical energy, without going through heat exchange process. Of all different types of fuel cells, the Proton Exchange Membrane Fuel Cell (PEMFC) is one of the most promising power sources for stand-alone utility and electric vehicle applications. Platinum (Pt) Catalyst is used for both fuel and air electrodes in PEMFCs. However, carbon monoxide (CO) contamination of $\mathrm{H}_{2}$ greatly affects electro catalysts used at the anode of PEMFCs and decreases cell performance. The irreversible poisoning of the anode can occur even in $\mathrm{CO}$ concentrations as low as few parts per million (ppm). In this work, we have synthesized several novel elctrocatalysts (Pt/C, $\mathrm{Pt} / \mathrm{Ru} / \mathrm{C}, \mathrm{Pt} / \mathrm{Mo} / \mathrm{C}, \mathrm{Pt} / \mathrm{Ir}$ and $\mathrm{Pt} / \mathrm{Ru} / \mathrm{Mo}$ ) for PEMFCs. These catalysts have been tested for $\mathrm{CO}$ tolerance in the $\mathrm{H}_{2}$ /air fuel cell, using $\mathrm{CO}$ concentrations in the $\mathrm{H}_{2}$ fuel that varies from 10 to 100 ppm. The performance of the electrodes was evaluated by determining the cell potential against current density. The effects of catalyst composition and electrode film preparation method on the performance of PEM fuel cell were also studied. It was found that at $70{ }^{\circ} \mathrm{C}$ and 3.5 atm pressure at the cathode, Pt-alloy catalyst $(10 \mathrm{wt} \% \mathrm{Pt} / \mathrm{Ru} / \mathrm{C}, 20 \mathrm{wt} \% \mathrm{Pt} / \mathrm{Mo} / \mathrm{C})$ were more $\mathrm{CO}$ tolerant than the $20 \mathrm{wt} \% \mathrm{Pt} / \mathrm{C}$ catalyst alone. It was also observed that spraying method was better than the brushing technique for the preparation of electrode film.
\end{abstract}




\section{TABLE OF CONTENTS}

$\begin{array}{lll}\text { Title page } & \text { i }\end{array}$

$\begin{array}{ll}\text { Disclaimer } & \text { ii }\end{array}$

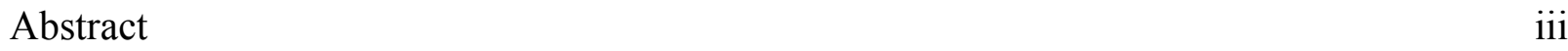

Table of Contents $\quad$ iv

List of Figures $\quad$ V

Executive Summary vi vi

Introduction $\quad 1$

$\begin{array}{ll}\text { Materials and Methods } & 2\end{array}$

Results and Discussion $\quad 4$

$\begin{array}{ll}\text { Conclusions } & 10\end{array}$

$\begin{array}{lr}\text { References } & 10\end{array}$ 


\section{LIST OF FIGURE}

Figure 1: Schematic of PEMFC experimental set-up for evaluation of catalysts and MEAs

Figure 2: Schematic of laboratory PEM fuel cell (FC05-01SP) for MEA study

Figure 3: Effect of carbon monoxide composition in commercial MEA $(20 \mathrm{wt} \% \mathrm{Pt} / \mathrm{C})$ compared with baseline case

Figure 4: Performance curves of synthesized MEAs with commercial catalysts (10 $\mathrm{wt} \% \mathrm{Pt} / \mathrm{C}$ and $20 \mathrm{wt} \% \mathrm{Pt} / \mathrm{C}$ ) prepared by brushing technique

Figure 5: Performance curves of synthesized MEAs with commercial catalysts (10 wt $\% \mathrm{Pt} / \mathrm{C}$ and $20 \mathrm{wt} \% \mathrm{Pt} / \mathrm{C}$ ) prepared by spraying technique

Figure 6: $\mathrm{CO}$ tolerance of MEAs prepared by spraying technique using 10 and $20 \mathrm{wt} \% \mathrm{Pt} / \mathrm{Ru} / \mathrm{C}(1: 1)$ synthesized catalysts

Figure 7: Effect of $\mathrm{CO}$ concentration on the performance of synthesized MEAs using synthesized $20 \mathrm{wt} \% \mathrm{Pt} / \mathrm{C}$ catalyst in PEMFC

Figure 8: Effect of $\mathrm{CO}$ concentration on the performance of synthesized MEAs using synthesized $20 \mathrm{wt} \% \mathrm{Pt} / / \mathrm{Ru} / \mathrm{C}$ catalyst in PEMFC

Figure 9: Effect of $\mathrm{CO}$ concentration on the performance of synthesized MEAs using synthesized $20 \mathrm{wt} \% \mathrm{Pt} / \mathrm{Ir} / \mathrm{C}$ catalyst in PEMFC

Figure 10: Effect of $\mathrm{CO}$ concentration on the performance of synthesized MEAs using synthesized $20 \mathrm{wt} \% \mathrm{Pt} / \mathrm{Ru} / \mathrm{Mo} / \mathrm{C}$ catalyst in PEMFC 


\section{EXECUTIVE SUMMARY}

In an effort to develop CO-tolerant electrocatalyst for PEMFCs, we synthesized a number of Ptbased bimetallic and tri-metallic catalysts. The catalysts were evaluated in a $\mathrm{H}_{2} /$ air fuel cell. The effects of temperature, and catalyst compositions on PEMFCs performance were studied. Several Pt-alloy catalysts (alloyed with $\mathrm{Ru}, \mathrm{Mo}$ and ,Ir) were tested for CO-tolerance in the $20 \mathrm{ppm}$ to $100 \mathrm{ppm}$ range. The newly synthesized $20 \mathrm{wt} \% \mathrm{Pt} / \mathrm{Ru} / \mathrm{C}$ electro catalyst in MEA can tolerate $\mathrm{CO}$ poisoning in PEMFC at $20 \mathrm{ppm} \mathrm{CO}$-contaminating $\mathrm{H}_{2}$-fuel and outperforms commercial $20 \mathrm{wt} \%$ $\mathrm{Pt} / \mathrm{C}$ in MEA. Our synthesized $20 \mathrm{wt} \% \mathrm{Pt} / \mathrm{Ru} / \mathrm{Mo} / \mathrm{C}$ electrocatlyst showed excellent $\mathrm{CO}$ tolerance in PEMFC and compared very favorably with $20 \mathrm{wt} \% \mathrm{Pt} / \mathrm{Ru} / \mathrm{C}$ in CO-tolerance. Using $\mathrm{Ru}$ and/or Mo in combination with Pt in electro catalyst formulation, the loading of Pt can be reduced significantly without compromising cell performance. Furthermore, we conclude that, to develop low cost, CO-tolerant catalysts for use in MEAs one needs to include metals like Ru and Mo in combination with Pt in the catalyst formulation. For optimum cell performance, finetuning of these metal compositions in the catalyst would be necessary. 


\section{INTRODUCTION}

Fuel cells are electrochemical devices that convert the available chemical free-energy directly into electrical energy, without going through the heat exchange process. Earlier, it was thought that, this type of energy would be used only for some special purposes like space travel. In recent years, there have been growing interests in developing fuel cell technologies for downto-earth applications. Because of the high efficiency and almost zero emission to the environment, these fuel cells are finding applications in chemical process industries (CPI) as stand-alone or on-site power generators and in vehicular transport. The present state-of-art Proton-Exchange Membrane Fuel Cell (PEMFC) technology is based on platinum (Pt) as a catalyst for both the fuel and air electrodes. This catalyst is highly active but susceptible to poisoning by fuel impurities such as, $\mathrm{S}$ and $\mathrm{CO}$, which may be present in the fuel used or may be introduced during the fuel processing such as, reforming. These impurities poison the anode irreversibly and decrease the performance of the PEMFCs [1]. This irreversible poisoning of the anode can happen even in CO concentrations as low as few ppm (parts per million), and therefore, require expensive scrubbing of the $\mathrm{H}_{2}$-fuel to reduce the contaminant concentration to acceptable level [2].

To reach full commercialization, cost reduction of the PEMFC stack and ancillary systems are required. For any commercial PEMFC, the fuel hydrogen has its source from the hydrocarbon fuels. These fuels when combined with steam, give $\mathrm{CO}$ and $\mathrm{H}_{2}$, where this $\mathrm{CO}$ is converted to $\mathrm{CO}_{2}$ in a shift reactor [3]. The residual $\mathrm{CO}$ concentration $(<1 \%)$ leaving the reactor is too high for the PEMFCs. This CO preferentially adsorbs on the platinum catalyst surface and blocks the access of hydrogen to the catalyst sites [4]. In order to reach optimum performance in commercial scale fuel cells, the optimization of electro-chemical activity over the whole electrode is of prime importance [2,5]. The presence of $\mathrm{CO}$ as contaminant $(>10 \mathrm{ppm})$ in the fuel $\mathrm{H}_{2}$ is known to be detrimental to the Pt-catalysts in PEMFC. This impurity causing large polarization loss reduces the PEMFC efficiency and power output [6,7].

To get an improved efficiency and output, development of metal alloy catalysts for fuel cell electrodes in particular Pt/Mo catalysts are of interest due to their high $\mathrm{CO}$ tolerance level relative to Pt metal catalyst [1]. From economic considerations, there is renewed interest in preparing fuel cell anode catalyst on conducting carbon support to minimize the amount of noble metal required in a working fuel cell. In order to commercialize this environmentally sound 
source of energy/power system, development of suitable CO-tolerant catalyst is needed. The cost and reliability of electro-catalyst in PEMFCs are major impediments in commercial application. Innovations are needed to reduce system costs and to enhance operating life before fuel cell can become commercially competitive with conventional power generating systems.

In our laboratory, we synthesized several Pt-based bimetallic and tri-metallic catalysts for PEMFC electrodes. In this report, we present our preliminary results on the performance of the membrane electrode assemblies (MEA) in $\mathrm{CO}$ contaminated $\mathrm{H}_{2}$ fuel.

\section{MATERIALS AND METHODS}

The major objective of this work was to develop low-cost CO-tolerant electro-catalysts for PEMFCs and demonstrate the feasibility of a $\mathrm{H}_{2} /$ air fuel cell based on these materials. Part of the work was focused on developing procedure for preparing metal catalysts loaded on carbon matrix. Novel catalysts are combined with the known high activity of the $\mathrm{Pt}$ and other noble/transition metals, such as $\mathrm{Pt} / \mathrm{Ru}, \mathrm{Pt} / \mathrm{Mo}, \mathrm{Pt} / \mathrm{Ru} / \mathrm{Mo}$, and $\mathrm{Pt} / \mathrm{Ir}$.

\section{Catalyst Preparation}

The metal catalysts were prepared by reducing the respective metallic chlorides. Chlorides of $\mathrm{Pt}, \mathrm{Ru}, \mathrm{Mo}$ and $\mathrm{Ir}$ were obtained from ElectroChem, Inc. These salts of the respective metals chosen for the candidate electrocatalysts were mixed in appropriate proportion and dissolved in distilled water. Sodium bisulfite was added slowly in the solution to form metal sulfite colloids. Hydrogen peroxide was then added to the colloid suspension to convert sulfite species to respective oxides. High surface area powered carbon (Vulcan XC-72) was added to the oxide colloid suspension to load the metal oxide on the carbon. Then hydrogen was bubbled through the suspension at $60{ }^{\circ} \mathrm{C}$ to reduce the oxides to the respective metals. Primary variables of the electrocatalysts synthesis were the catalyst components, proportion of the various metals, and total metal loading on the carbon. The total metal loading on the carbon was up to $1 \mathrm{mg} / \mathrm{cm}^{2}$ of the electrode surface area.

\section{Preparation of MEA}

The membrane electrode assemblies (MEAs) were fabricated by both brushing and spraying techniques The brushing and spraying methods were judged most useful in electrode film laying [8,9]. 
Thin film MEA with a Nafion 112 membrane was prepared from slurry containing Nafion, Teflon, and catalyzed carbon. This slurry was prepared by mixing catalyzed carbon with $5 \%$ Nafion solution and Teflon suspension. Thinning of the slurry to the required extent was accomplished by adding appropriate amounts of either $30 \mathrm{wt} \% \mathrm{t}$-butanol or distilled water. The Nafion content of the electrode was varied in the range 20 to $40 \mathrm{wt} \%$. The Teflon loading was varied in the range 1 to $30 \mathrm{wt} \%$. The catalyzed carbon slurry was coated on both side of a Nafion 112 membrane by brushing. Electrodes were then placed on both sides of a Nafion 112 membrane and then assembly was hot pressed at $120{ }^{\circ} \mathrm{C}$ and 138 bars for 2 minutes. Chemical treatment of the Nafion membrane prior to coating was done by boiling in $0.5 \mathrm{M}$ sulfuric acid for 30 minutes, and then finally rinsed several times in de-ionized water.

Membrane electrode assemblies were also prepared by spraying method. Slurry preparation technique was the same as described above. Instead of brushing, the slurry was sprayed on both sides of the Nafion 112 membrane and the substrate was maintained at $120{ }^{\circ} \mathrm{C}$ to evaporate the solvents and to insure the homogeneity of the active layer. Then the assemblies were hot pressed for 2 minutes at 138 bars and $120{ }^{\circ} \mathrm{C}$. The advantage of spraying is that it produces thinner membrane than the brushing and requires shorter time. The details of the brushing and spraying methods are given elsewhere [10].

\section{Experimental Set-up}

The experimental set-up used for testing and evaluation of catalysts and MEAs in a PEMFC is shown schematically in Figure 1 . In the PEMFC, $\mathrm{H}_{2} /$ air electrodes were used. The gases used in this PEMFC evaluation work were obtained from Air Products. High purity hydrogen (UN 1049) was used as fuel. Ultra pure carrier grade compressed air (UN 1002) was used a source of oxygen. A 100 ppm CO in hydrogen (ID 40094) was used as a source of CO contaminant in the fuel. A Multiple Dyna-Blender (Matheson Model 8284), which consisted of a flow indicator and controller, a mixer (Model 8270), and a transducer (model 8272) was used to control the flow of these gases and to mix $\mathrm{CO}$ with hydrogen in different proportion for the fuel cell. A HP GC 5890 was used to crosscheck the $\mathrm{CO} / \mathrm{H}_{2}$ composition.

In the fuel cell, water is produced due to electrochemical reaction between hydrogen and oxygen. Two water traps (WT) were installed at the outlets of fuel cell to remove water as needed. Two back-pressure regulators (BPR) were used to maintain constant pressure in the fuel cell. Exit gases from the fuel cell (FC) were then taken to the fume hood (FH). As highly 
poisonous $\mathrm{CO}$ gas was used, the fuel cell system needed to be maintained in a negative pressure environment in the fume hood. The fuel cell hardware used in the work was obtained from Electrochem, Inc., Model FC05-01SP. As shown in Figure 2, this is a laboratory scale fuel cell for the fundamental study of membrane electrode assembly (MEA) and fuel cell operation. Thermostats installed on each of the current collector plates prevented overheating of this type of fuel cell hardware. At each temperature, pressure and flow rate, and for all MEAs, the voltage and current were read and recorded using two multi-meters.

The MEA was placed in a graphite cell with the carbon cloth current collector pressed against the MEA. Carbon cloths were wet-proofed by treatment with a $10 \%$ Teflon suspension, followed by heating at $270{ }^{\circ} \mathrm{C}$ for 20 minutes. This was done to facilitate gas diffusion and the rejection of water from the cathode. Graphite cell plates had grooves on one side to assists a uniform distribution of the reactant gases. The effective mass transfer area of the MEA was about $5 \mathrm{~cm}^{2}$. The PEMFC was operated at $70{ }^{\circ} \mathrm{C}$ and the pressure on cathode and anode sides were maintained at $3.5 \mathrm{~atm}$ and $2 \mathrm{~atm}$, respectively. For each catalyst and/or MEA, the experiment was run for 72 hours. The cell performance was evaluated as a function of temperature, flow rate, composition of catalyst and the MEA preparation method.

\section{RESULTS AND DISCUSSIONS}

A number of electrocatalysts were prepared and evaluated for CO tolerance in PEMFCs. The following catalysts were prepared by the co-deposition method:

$\begin{array}{ll}10 \mathrm{wt} \% \mathrm{Pt} \text { on Carbon } & 20 \mathrm{wt} \% \mathrm{Pt} \text { on Carbon } \\ 10 \mathrm{wt} \% \mathrm{Pt} / \mathrm{Ru}(1: 1) \text { on Carbon } & 20 \mathrm{wt} \% \mathrm{Pt} / \mathrm{Ru}(1: 1) \text { on Carbon } \\ 20 \mathrm{wt} \% \mathrm{Pt} / \mathrm{Ir}(1: 1) \text { on Carbon } & 20 \mathrm{wt} \% \mathrm{Pt} / \mathrm{Ru} / \mathrm{Mo}(1 / 3: 1 / 3: 1 / 3) \text { on Carbon }\end{array}$

Each of the catalysts used in the MEA was tested in PEMFC with pure and CO-contaminated hydrogen fuel.

A commercial MEA obtained from ElectroChem, Inc., having $20 \mathrm{wt} \% \mathrm{Pt} / \mathrm{C}$ was used to obtain the baseline performance curve of the PEMFC. The performance curve is a plot of voltage against current density at specified temperature and fuel/oxidant flow rates. In the experiment, the ratio of hydrogen to air was maintained at the stoichiometric proportions (2:1). Usually with increasing temperature, the cell performance improves. In the PEMFC, however, the operating temperature of the cell is dictated by the upper temperature limit of the polymer membrane used 
in the MEA. In this case, the upper limit was set to $75^{\circ} \mathrm{C}$ without humidification. All runs were made at a lower temperature, i.e., $70{ }^{\circ} \mathrm{C}$. In PEMFC operation, the anode side was maintained at $2 \mathrm{~atm}$ pressure while the cathode side operated at $3.5 \mathrm{~atm}$. These values were taken from the literature that gave better performance on PEMFC [2]. With an airflow rate of $1900 \mathrm{sccm}$ and 70 ${ }^{\circ} \mathrm{C}$, the performance curve of the cell is similar to that of a typical commercial PEMFC. This is shown in Figure 3 as the baseline case for pure hydrogen fuel.

The commercial MEA (20 wt $\% \mathrm{Pt} / \mathrm{C}$ ) was exposed to contaminant $\mathrm{CO}$ in hydrogen fuel in PEMFC. The performance curves at two CO concentration levels (20 ppm and $100 \mathrm{ppm}$ ) are also shown in Figure 3. Although Pt is one of the most effective catalysts for electro-oxidation, it is susceptible to $\mathrm{CO}$ poisoning due to strong chemisorption. With increasing $\mathrm{CO}$ concentration, the cell performance deteriorates very rapidly. When compared with the baseline performance curve (with pure $\mathrm{H}_{2}$ ), 100 ppm CO contaminated $\mathrm{H}_{2}$ had more poisoning effect on Pt/C MEA than the $20 \mathrm{ppm} \mathrm{CO}$ contaminated $\mathrm{H}_{2}$. The results clearly show that the Pt catalyst cannot tolerate $\mathrm{CO}$. Presence of trace amount of $\mathrm{CO}$ would compromise the fuel cell performance.

Membrane Electrode Assemblies (MEAs) were prepared using commercial catalysts by brushing and spraying methods. The MEAs were prepared with catalyst loading of $20 \mathrm{wt} \% \mathrm{Pt} / \mathrm{C}$ and $10 \mathrm{wt} \% \mathrm{Pt} / \mathrm{C}$. These MEAs were tested for cell performance in PEMFC with 20 and 100 ppm of CO contaminated hydrogen. The baseline performance curve was also obtained with pure hydrogen fuel. The performance curves of the PEMFC with MEAs prepared by brushing technique, having $10 \mathrm{wt} \%$ and $20 \mathrm{wt} \% \mathrm{Pt} / \mathrm{C}$ are shown in Figure 4 . The baseline performance of PEMFC using $20 \mathrm{wt} \% \mathrm{Pt} / \mathrm{C}$ is similar to that of commercial MEA Performance curves of $20 \mathrm{wt} \%$ $\mathrm{Pt} / \mathrm{C}$ electro-catalyst at two CO concentration levels (20 ppm and $100 \mathrm{ppm}$ ) are shown in Figure 4. With increasing $\mathrm{CO}$ concentration, the cell performance decreases very rapidly. Compared with baseline performance curve, $100 \mathrm{ppm} \mathrm{CO}$ contaminated $\mathrm{H}_{2}$ had pronounced poisoning effect on $20 \mathrm{wt} \% \mathrm{Pt} / \mathrm{C}$ MEA than the $20 \mathrm{ppm} \mathrm{CO}$ contaminated $\mathrm{H}_{2}$. It was also observed that in the presence of $20 \mathrm{ppm} \mathrm{CO}$, the performance decreases with decreasing catalyst loading. A close review of the two performance curves for 20 and $10 \mathrm{wt} \% \mathrm{Pt} / \mathrm{C}$ MEAs operated with $20 \mathrm{ppm} \mathrm{CO}$ shows that low catalyst loading leads to faster deterioration of cell performance. This may be attributed to reduce active catalyst sites (active surface area) at lower catalyst loading. As a result, one would expect rapid loss of active sites by $\mathrm{CO}$ poisoning. With increasing Pt loading, better cell performance may be achieved but $\mathrm{CO}$ poisoning remains a problem. 
In Figure 5, performance of the PEMFC with MEAs prepared by spraying technique, with $10 \mathrm{wt} \%$ and $20 \mathrm{wt} \% \mathrm{Pt} / \mathrm{C}$ are shown. The materials used in these MEAs are exactly same as before, but a spraying method was used in the laying of the electrode assembly. The baseline performance of the PEMFC with $20 \mathrm{wt} \% \mathrm{Pt} / \mathrm{C}$ in the synthesized MEA was similar to that of commercial MEA. Performance curves of $20 \mathrm{wt} \% \mathrm{Pt} / \mathrm{C}$ electro-catalyst at two CO concentration levels (20 ppm and $100 \mathrm{ppm}$ ) are shown in Figure 5. A comparison of the performance curves in Figure 4 with that in Figure 5 show that the characteristics of the curves are very similar both in presence of CO contaminant hydrogen and pure hydrogen fuel in the PEMFC. However, a close look at each of the curves shows that spraying method yielded better performance curve than the brushing method in preparing MEAs. By using the spraying method, it is possible to lay a homogeneous active layer of catalyst with uniform particle distribution and thickness. This may account for the better performance of MEAs. In our subsequent work, the spraying method was consistently used in all MEA preparation.

Using the spraying technique, two MEAs were prepared with 10 and $20 \mathrm{wt} \% \mathrm{Pt} / \mathrm{Ru} / \mathrm{C}$ catalysts. Performance curves of these MEAs in the PEMFC are shown in Figure 6. When compared with Pt/C MEAs (Figure 3) with that of Pt/Ru/C MEAs, it appears that the presence of ruthenium $(\mathrm{Ru})$ in the electrocatalysts provide improved $\mathrm{CO}$ tolerance. At high $\mathrm{CO}$ concentration $(>100 \mathrm{ppm})$, there is a significant drop in cell performance even with $\mathrm{Pt} / \mathrm{Ru} / \mathrm{C}$ catalyst. At low CO concentration (20 ppm), MEAs with $10 \mathrm{wt} \%$ and $20 \mathrm{wt} \% \mathrm{Pt} / \mathrm{Ru} / \mathrm{C}$ showed that the two formulations are equally good. Thus, it appears that at low $\mathrm{CO}$ concentration, one may opt to use $\mathrm{Ru}$ in place of $\mathrm{Pt}$ to reduce Pt loading in the catalyst.

In an effort to find CO-tolerant catalyst, a number of bi- and tri-metallic catalysts of $\mathrm{Pt}$ in combination with $\mathrm{Ru}$, Ir and Mo were synthesized for use in MEAs. The metal salts used in the catalyst synthesis were obtained from Fisher Scientific. The MEAs were prepared by spraying method as stated earlier. All MEAs were evaluated in the PEMFC with pure hydrogen fuel and 20 and 100 ppm CO contaminated hydrogen fuel, respectively. The fuel cell operated at $70{ }^{\circ} \mathrm{C}$ with anode and cathode side gas pressure of $2 \mathrm{~atm}$ and $3.5 \mathrm{~atm}$, respectively. The performance curve of the $20 \mathrm{wt} \% \mathrm{Pt} / \mathrm{C}$ MEA is shown in Figure 7. The performance of our synthesized MEA was very much similar to that we obtained from a commercial vendor (ElectroChem, Inc.,), which can be seen by comparing the performance curves of Figure 3 with that of Figure 7 . 
The performance curve of the 1:1 Pt/Ru $20 \mathrm{wt} \% \mathrm{MEA}$ is shown in Figure 8. The MEAs were evaluated at 20 and $100 \mathrm{ppm}$ CO contamination in the hydrogen fuel. A comparison of the performance curves of $\mathrm{Pt} / \mathrm{C} 20 \mathrm{wt} \% \mathrm{MEA}$ in Figure 7 with that of Figure 8 clearly demonstrate that $\mathrm{Pt} / \mathrm{Ru} / \mathrm{C} 20 \mathrm{wt} \%$ MEA was tolerant to $\mathrm{CO}$ poisoning. In fact, $\mathrm{Pt} / \mathrm{Ru} / \mathrm{C} \mathrm{MEA}$ yielded a better baseline performance when we compare that with Pt/C MEA of Figure 7. Furthermore, we observed that at $20 \mathrm{ppm} \mathrm{CO}$ contamination the performance of the $\mathrm{Pt} / \mathrm{Ru} / \mathrm{C} \mathrm{MEA}$ was as good as the baseline performance curve of $\mathrm{Pt} / \mathrm{C}$ MEA. This shows that ruthenium is a potent $\mathrm{CO}$ tolerant catalyst and may be useful as a substitute of platinum for reduced Pt-catalyst loading.

Electrocatlyst of $\mathrm{Pt} / \mathrm{Ir}$ was synthesized in 1:1 ratio for preparation of $\mathrm{Pt} / \mathrm{Ir} / \mathrm{C} 20 \mathrm{wt} \%$ MEA. The performance curve of this MEA is shown in Figure 9. This MEA is also sensitive to $\mathrm{CO}$ contaminant. A comparison of Figure 7 with that of Figure 9 reveals that $\mathrm{Pt} / \mathrm{Ir} / \mathrm{C} 20 \mathrm{wt} \%$ MEA performs better than Pt/C $20 \mathrm{wt} \%$ MEA both in terms of baseline voltage/current density and $\mathrm{CO}$ tolerance. However, comparing the performance of $\mathrm{Pt} / \mathrm{Ir} / \mathrm{C} 20 \mathrm{wt} \% \mathrm{MEA}$ in Figure 9 with that of $\mathrm{Pt} / \mathrm{Ru} / \mathrm{C} 20 \mathrm{wt} \% \mathrm{MEA}$ in Figure 8, the later is found to have better performance characteristics. Like ruthenium, iridium could also be a choice of catalyst for CO tolerance and may be used to substitute for platinum for reduced Pt-loading in catalyst formulation. From $\mathrm{CO}$ tolerance point of view it appears that both $\mathrm{Pt} / \mathrm{Ir} / \mathrm{C}$ and $\mathrm{Pt} / \mathrm{Ru} / \mathrm{C} 20 \mathrm{wt} \% \mathrm{MEAs}$ are attractive options over Pt/C $20 \mathrm{wt} \%$ MEA in PEMFC operations.

A three-component catalyst of $\mathrm{Pt}, \mathrm{Ru}$, and $\mathrm{Mo}$ in the weight proportion of $1 / 3,1 / 3$, and $1 / 3$ respectively was also synthesized. This catalyst was used to synthesize $\mathrm{Pt} / \mathrm{Ru} / \mathrm{Mo} / \mathrm{C} 20 \mathrm{wt} \%$ MEA. The performance curve of this MEA is shown in Figure 10. A comparison of the $\mathrm{Pt} / \mathrm{Ru} / \mathrm{C}$ $20 \mathrm{wt} \%$ MEA with that of $\mathrm{Pt} / \mathrm{Ru} / \mathrm{Mo} / \mathrm{C} 20 \mathrm{wt} \%$ MEA show that both the MEAs perform about the same level in terms of baseline voltage/current density and $\mathrm{CO}$ tolerance. By addition of molybdenum, fuel cell performance was not compromised but contributed to reduce Pt loading. Although we did not study sulfur poisoning of electrocatalysts, addition of Mo in catalyst formulation will provide added protection against sulfur poisoning.

\section{CONCLUSIONS}

Both synthesized and commercial Pt catalysts in the MEAs are susceptible to CO poisoning. From limited experimentation, we observed that for MEA preparation, spraying method is more effective than brushing. The cell performance can be improved by incorporating 
$\mathrm{Ru}$ and Mo in catalyst formulation in combination with Pt. The metal $\mathrm{Ir}$ in combination with $\mathrm{Pt}$ in the catalyst did not have any significant impact on cell performance. The newly synthesized $20 \mathrm{wt} \% \mathrm{Pt} / \mathrm{Ru} / \mathrm{C}$ electro catalyst in MEA can tolerate $\mathrm{CO}$ poisoning in PEMFC at $20 \mathrm{ppm} \mathrm{CO}-$ contaminating $\mathrm{H}_{2}$-fuel and outperforms commercial $20 \mathrm{wt} \% \mathrm{Pt} / \mathrm{C}$ in MEA. Our synthesized 20 $\mathrm{wt} \% \mathrm{Pt} / \mathrm{Ru} / \mathrm{Mo} / \mathrm{C}$ electrocatlyst showed excellent $\mathrm{CO}$ tolerance in PEMFC and compared very favorably with $20 \mathrm{wt} \% \mathrm{Pt} / \mathrm{Ru} / \mathrm{C}$ in $\mathrm{CO}$-tolerance. Using $\mathrm{Ru}$ and/or Mo in combination with $\mathrm{Pt}$ in electro catalyst formulation, the loading of Pt can be reduced significantly without compromising cell performance. Furthermore, we conclude that, to develop low cost, CO-tolerant catalysts for use in MEAs one needs to include metals like Ru and Mo in combination with $\mathrm{Pt}$ in the catalyst formulation. For optimum cell performance, fine-tuning of these metal compositions in the catalyst would be necessary.

\section{ACKNOWLEDGEMENTS}

This report was prepared with the support of U.S. Department of Energy, under Award No. DEFG26-98FT40146. Assistance from Dr. Ashoke Damle of RTI through a subcontract agreement with NCATSU (Contract No. 4-47072-SG-001) is greatly appreciated. However, any opinions, findings, and conclusions, or recommendations expressed herein are those of the authors and do not necessarily reflect the views of the DOE.

\section{REFERENCES}

1. Lee, S.J., Mukerjee, S., Ticianelli, E.A., and McBreen, J., Electrochemica Acta, 44, 3283 (1999).

2. Hirchenhofer, J.H., Stauffer, D.B., and Engleman, R.R., "Fuel Cells. A Handbook," U.S. Department of Energy, NETL, 1994.

3. Brown, D.R., "PEM Fuel Cells for Commercial Buildings," Document No. PNNL 12051, under Contact DE-AC06-76RLO 1830, U. S. Department of Energy, 1998.

4. Masel, R.I., "Principles of Adsorption and Reaction on Solid Surfaces", John Wiley \& Sons, 1996.

5. Leo, J., Bolmen, M.J., and Mugerwa, M.N., "Fuel Cell Systems", Plenum Press, New York, 1993.

6. H. Scott Fogler, "Elements of Chemical Reaction Engineering”, $2^{\text {nd }}$ edition, Prentice Hall, Englewood Cliffs, New Jersey, 1999.

7. Bockris, J.O.M., and Appleby, A.J., Energy, 11, 95 (1986).

8. Swathirajan, S., and Mikhall, Y.M., Electrochemical Society Proceedings, 97 (13), 158 (1997). 
9. Mosdale, R., Wakizoe, M., and Srinivasan, S., Electrochemical Society Proceedings, 97 (13), 139 (1997).

10. Sharmin, S., "Development of Novel Electrocatalysts for Proton Exchange Membrane Fuel Cells (PEMFCs)," MS Thesis, North Carolina A\&T State University, Greensboro, NC (2000). 
FIC: Flow Indicator and Controller GC: HP Gas Chromatograph

FH: Fume Hood

PC: Personal Computer

M: Multimeter
TIC: Temperature Indicator and Controller BPR: Back Pressure Regulator WT: Water Trap

FC: Fuel Cell Hardware

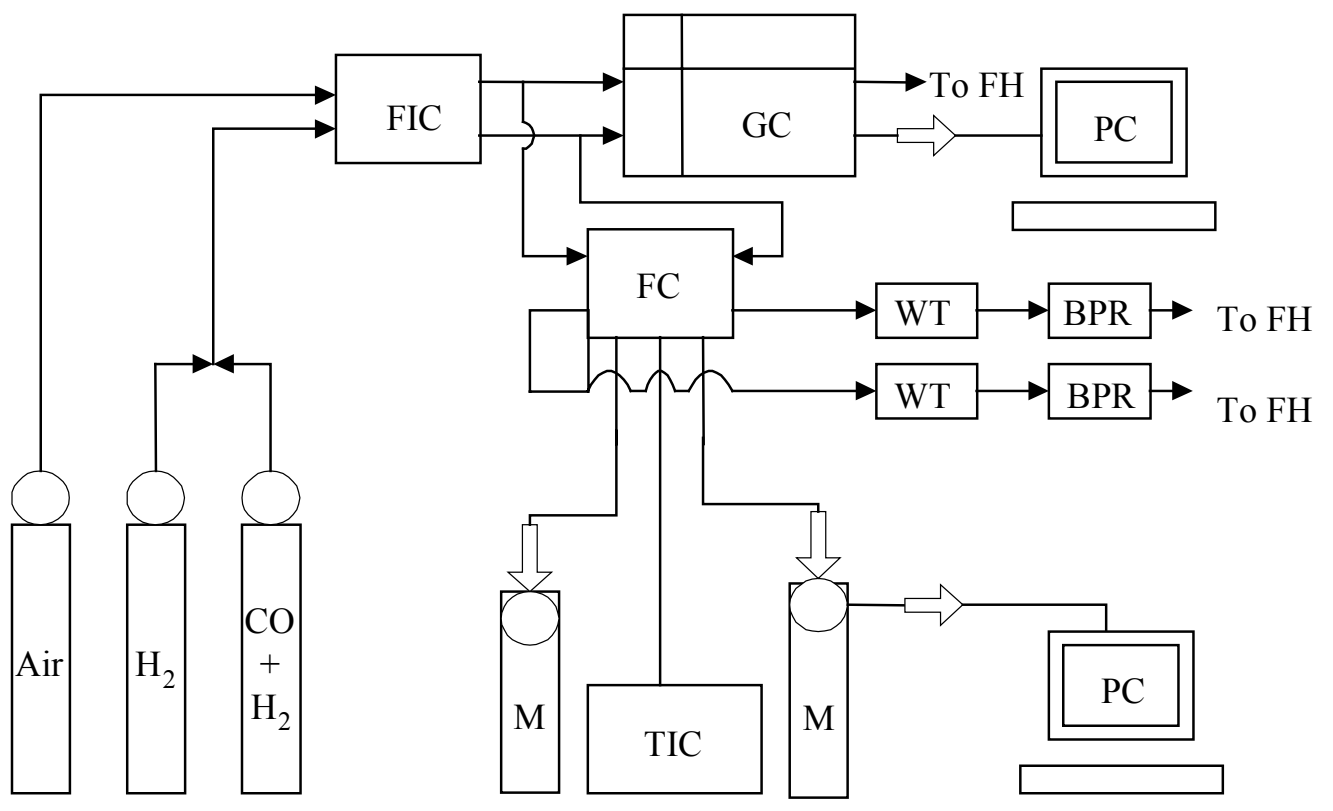

Figure 1: Schematic of PEMFC experimental set-up for evaluation of catalysts and MEAs

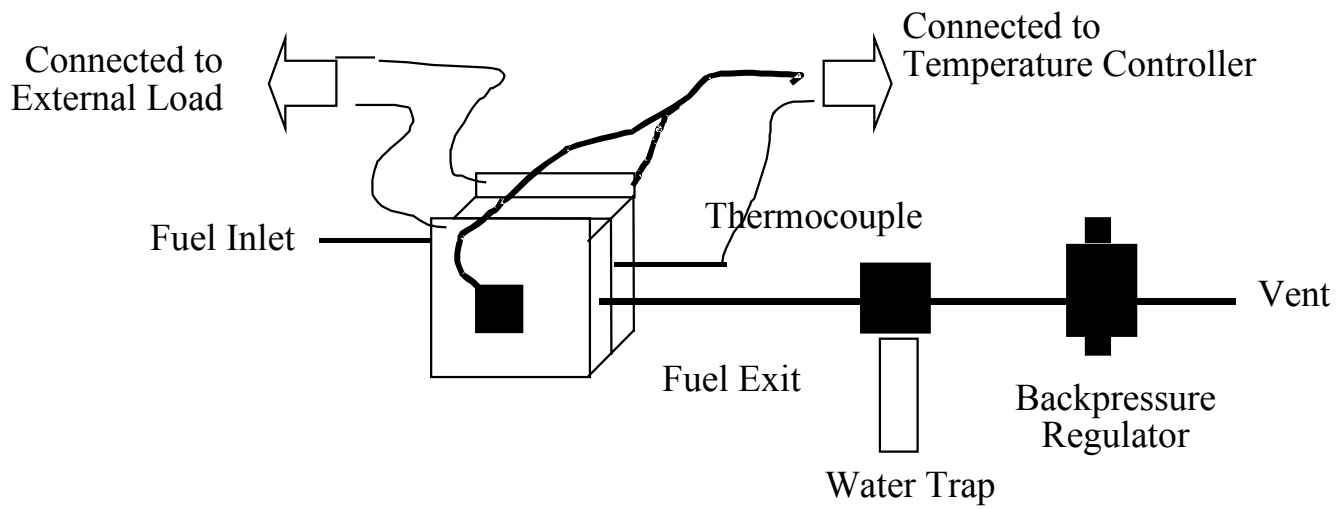

Figure 2: Schematic of laboratory PEM fuel cell (FC05-01SP) for MEA study 


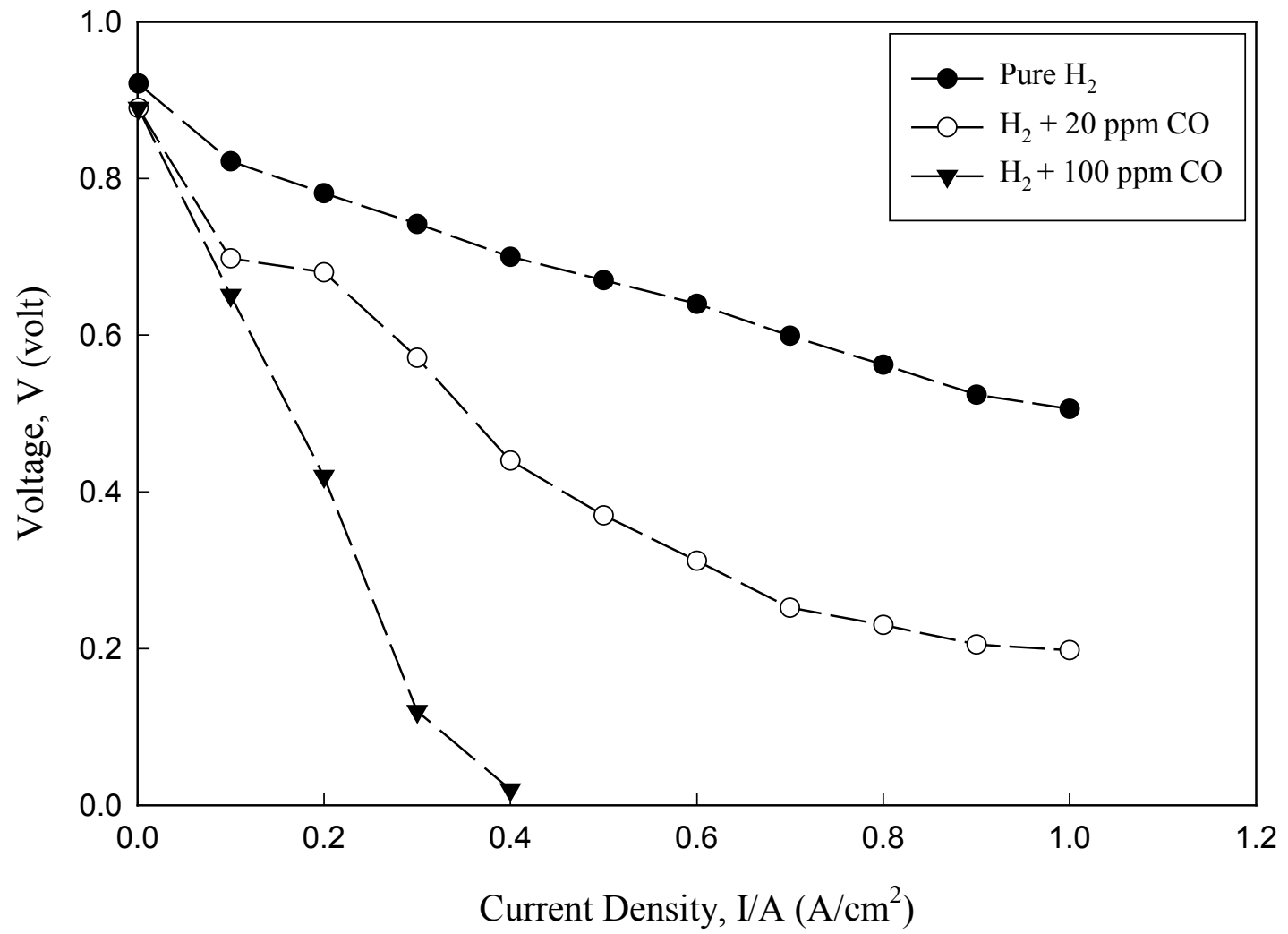

Figure 3: Effect of carbon monoxide composition in commercial MEA ( $20 \mathrm{wt} \% \mathrm{Pt} / \mathrm{C})$ compared with baseline case. 


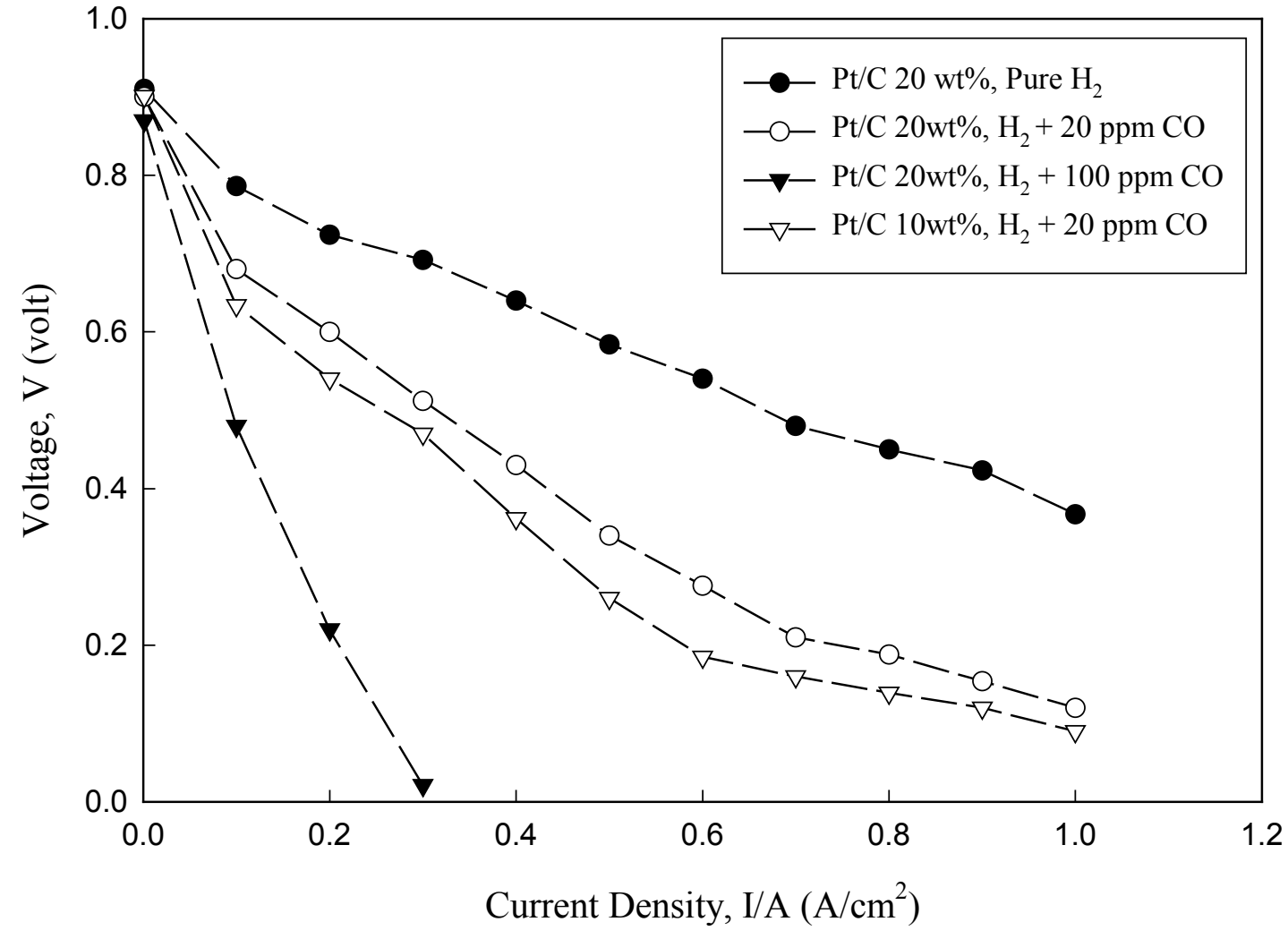

Figure 4: Performance curves of synthesized MEAs with commercial catalysts (10 wt $\% \mathrm{Pt} / \mathrm{C}$ and $20 \mathrm{wt} \% \mathrm{Pt} / \mathrm{C}$ ) prepared by brushing technique. 


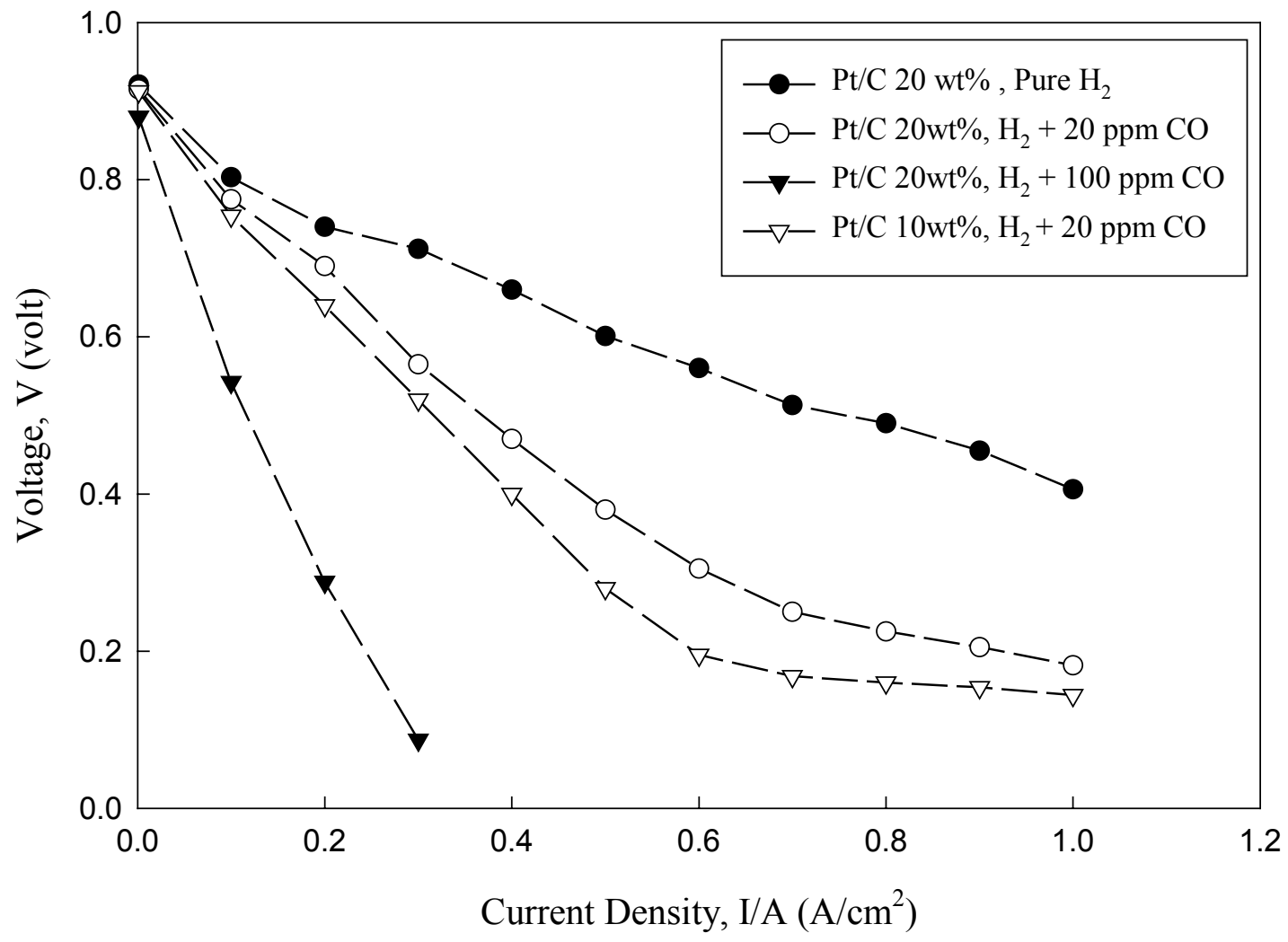

Figure 5: Performance curves of synthesized MEAs with commercial catalysts $(10 \mathrm{wt} \% \mathrm{Pt} / \mathrm{C}$ and $20 \mathrm{wt} \% \mathrm{Pt} / \mathrm{C}$ ) prepared by spraying technique. 


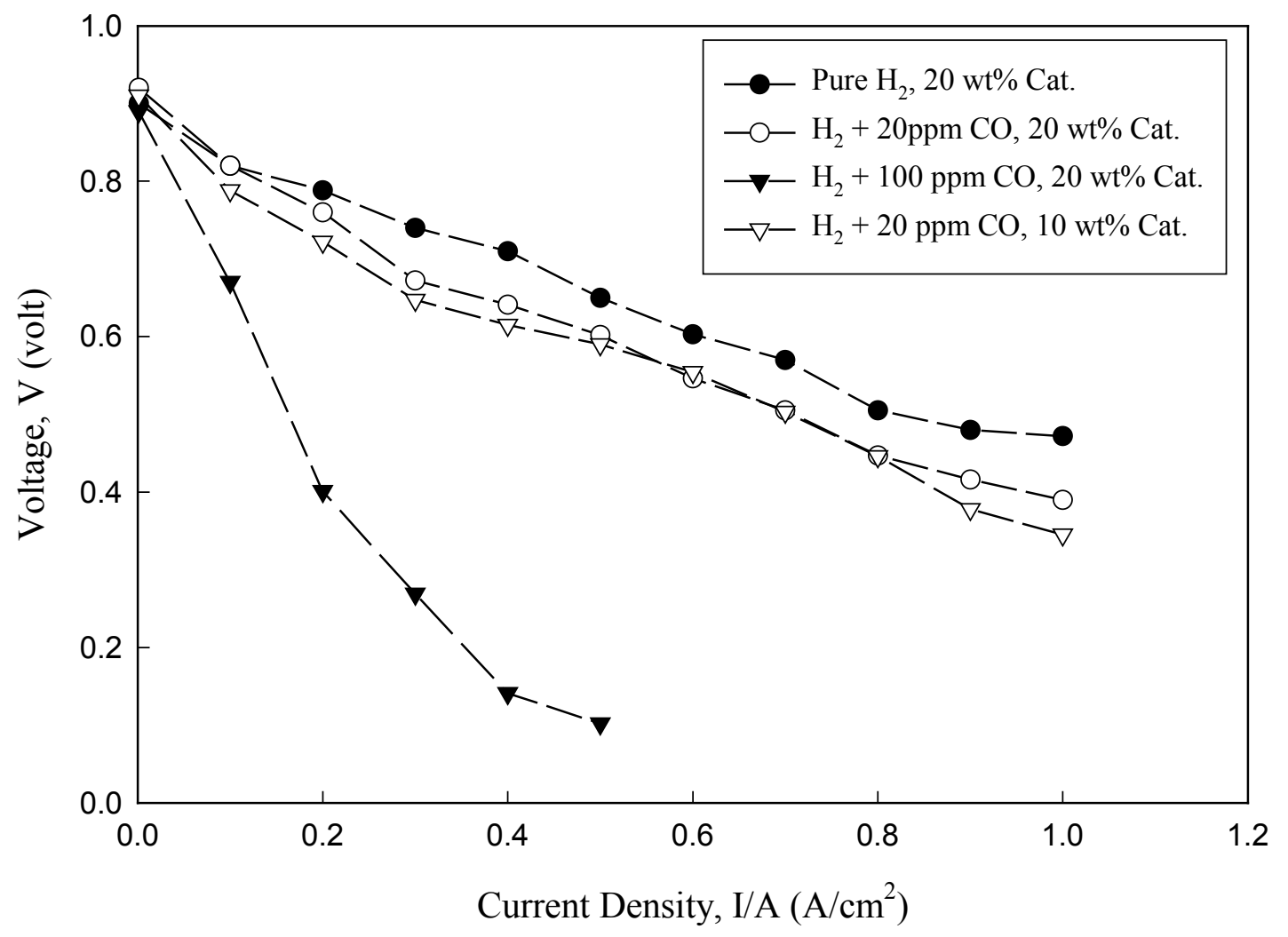

Figure 6: $\mathrm{CO}$ tolerance of MEAs prepared by spraying technique using 10 and $20 \mathrm{wt} \% \mathrm{Pt} / \mathrm{Ru} / \mathrm{C}$ (1:1) synthesized catalysts. 


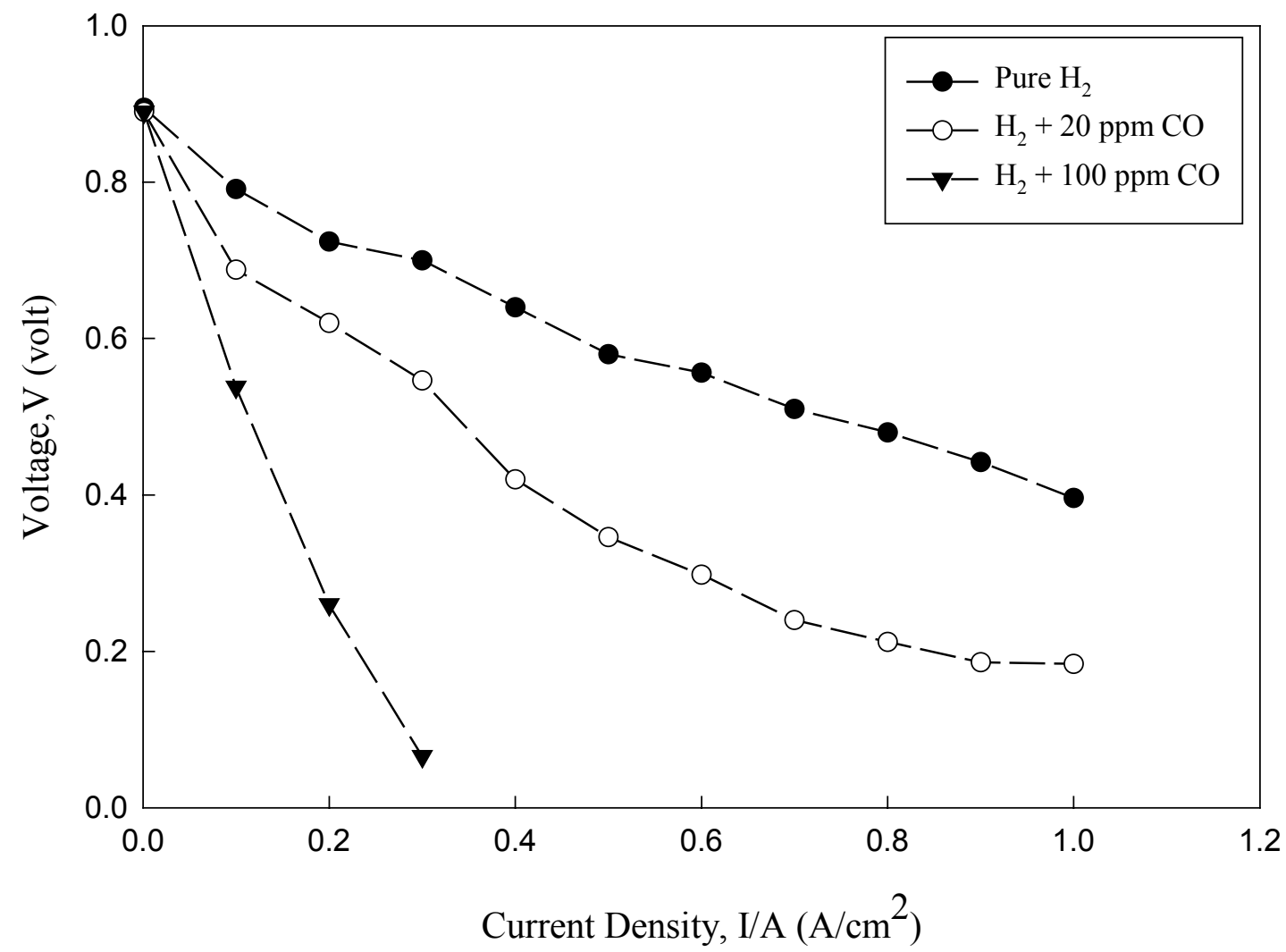

Figure 7: Effect of $\mathrm{CO}$ concentration on the performance of synthesized MEAs using synthesized $20 \mathrm{wt} \% \mathrm{Pt} / \mathrm{C}$ catalyst in PEMFC. 


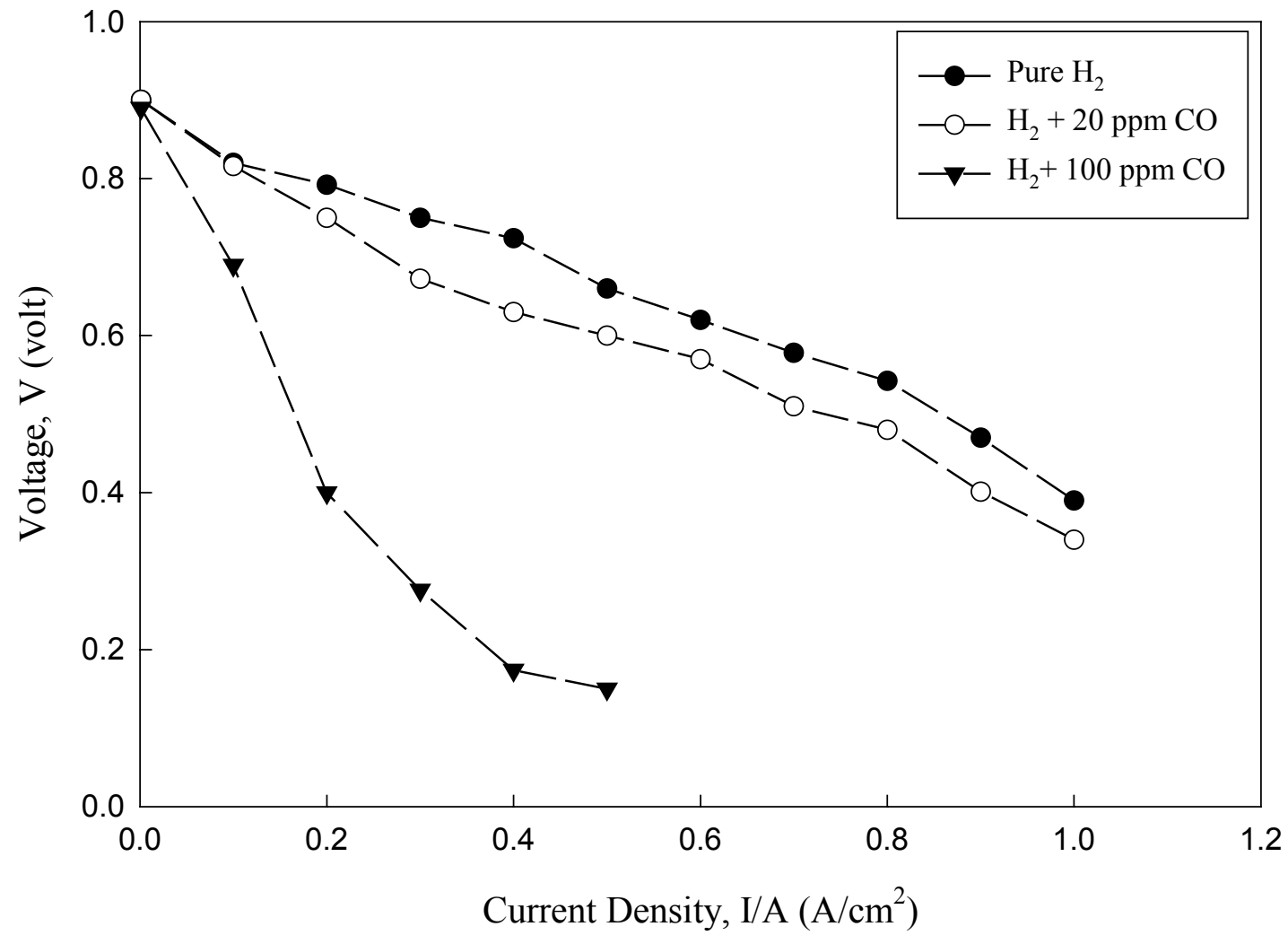

Figure 8: Effect of $\mathrm{CO}$ concentration on the performance of synthesized MEAs using synthesized $20 \mathrm{wt} \% \mathrm{Pt} / \mathrm{Ru} / \mathrm{C}$ catalyst in PEMFC. 


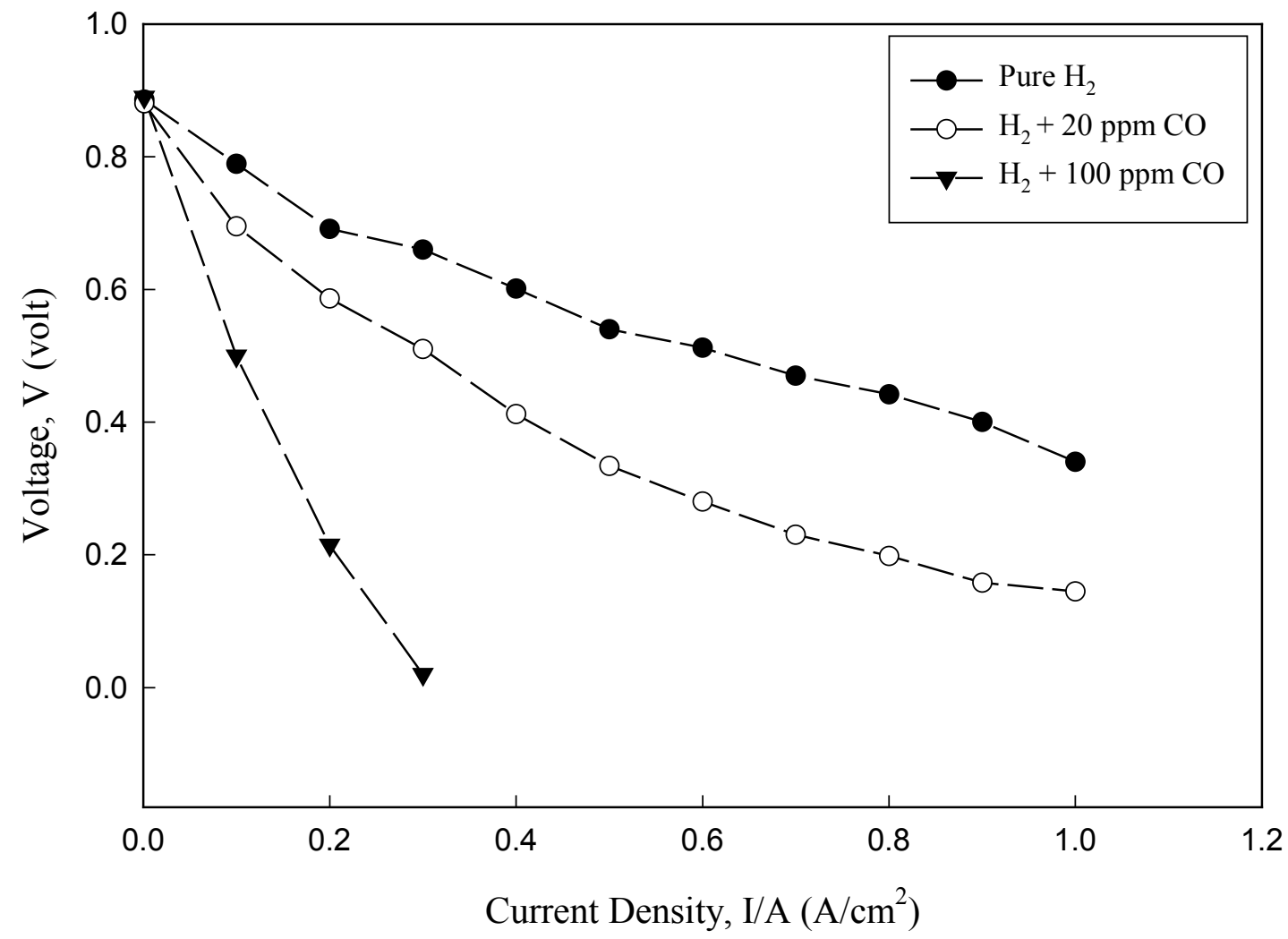

Figure 9: Effect of $\mathrm{CO}$ concentration on the performance of synthesized MEAs using synthesized $20 \mathrm{wt} \% \mathrm{Pt} / \mathrm{Ir} / \mathrm{C}$ catalyst in PEMFC. 


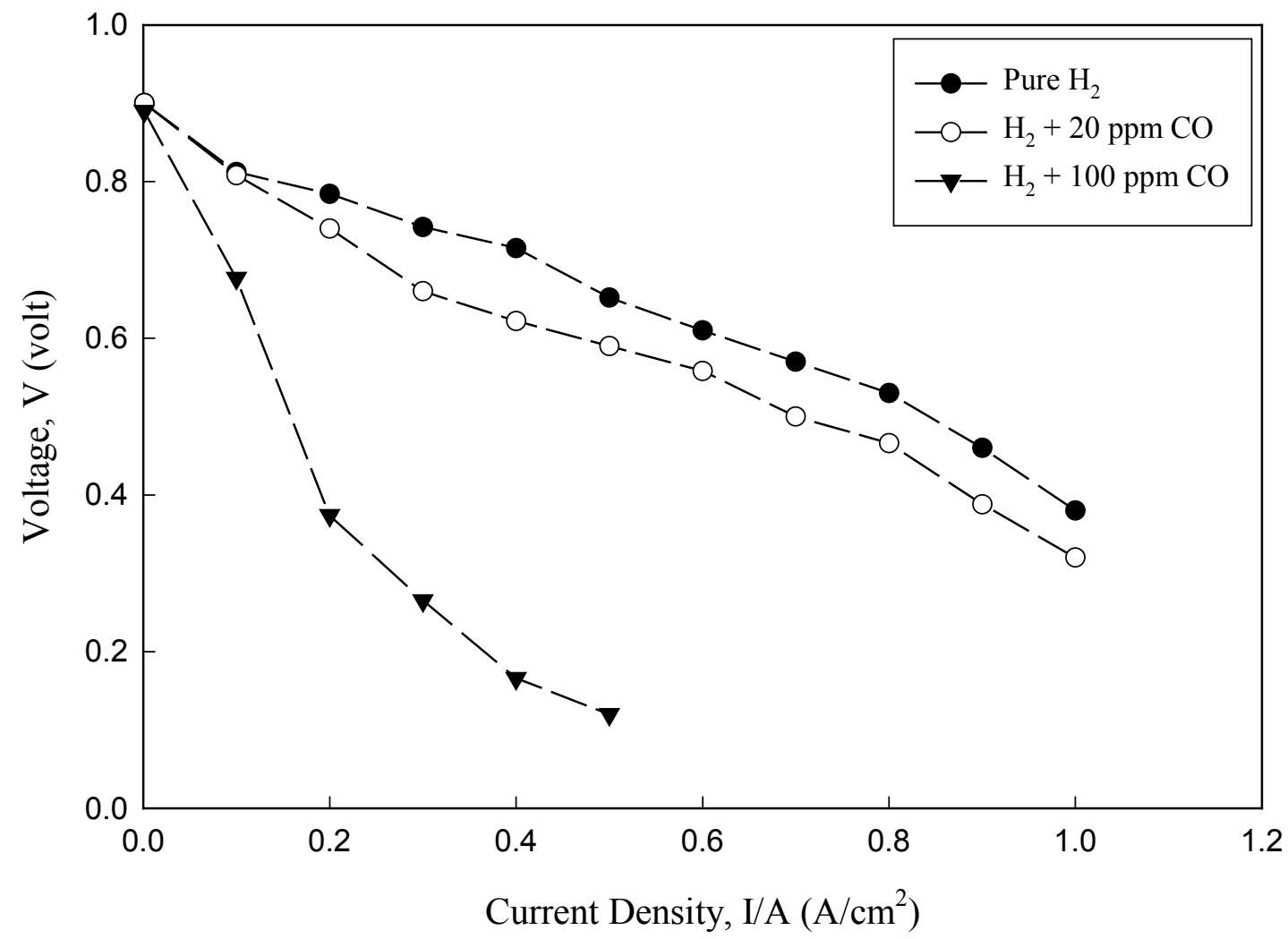

Figure 10: Effect of $\mathrm{CO}$ concentration on the performance of synthesized MEAs using synthesized $20 \mathrm{wt} \% \mathrm{Pt} / \mathrm{Ru} / \mathrm{Mo} / \mathrm{C}$ catalyst in PEMFC. 